\title{
Asterotremella humicola
}

National Cancer Institute

\section{Source}

National Cancer Institute. Asterotremella humicola. NCI Thesaurus. Code C127689.

A species of psychrotrophic, dimorphic yeast-like fungi in the phylum Basidiomycota and genus Asterotremella found in soil and water. This species has no sexual form. 